
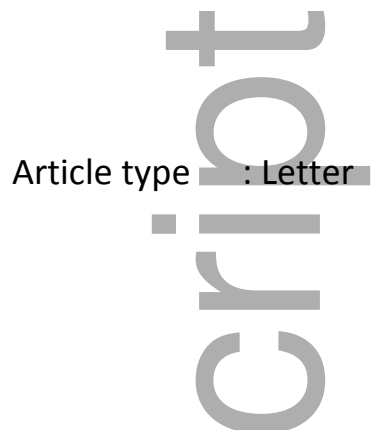

\title{
Polycystic Ovary Syndrome; an underestimated problem in primary care
}

Hamidreza Mani ${ }^{1,2}$, Miles J Levy ${ }^{2}$, Kamlesh Khunti ${ }^{1}$

1- University of Leicester, Diabetes Research Centre, Leicester Diabetes Centre, Leicester General Hospital, Leicester, LE4 5PW, UK

2- Department of Diabetes and Endocrinology, Leicester Royal Infirmary, University Hospitals of Leicester NHS Trust, Leicester, LE1 5WW, UK

Corresponding Author: Hamidreza Mani (manihr@yahoo.com).

Key Words: Polycystic ovary syndrome, primary care, education, database, monitoring

Conflicts of interest: None related to the presented work.

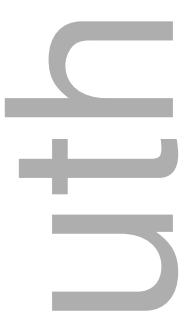

\section{Polycystic Ovary Syndrome; an underestimated problem in primary care}

This is the author manuscript accepted for publication and has undergone full peer review but has not been through the copyediting, typesetting, pagination and proofreading process, which may lead to differences between this version and the Version of Record. Please cite this article as doi: $10.1111 / \mathrm{ijcp} .13081$

This article is protected by copyright. All rights reserved 
Polycystic ovary syndrome (PCOS) is the most common endocrine condition in women of reproductive age with a reported prevalence of up to $15 \%$ (1). Women with PCOS are at higher risk of metabolic and mental health complications $(1,2)$. It is recommended that women with PCOS are monitored for these long-term health issues; especially T2DM and gestational diabetes (1). In a recent report from a UK primary care system, less than $8 \%$ were screened for diabetes within 2 years after a diagnosis of PCOS was made (3). This study was conducted in a population with a coded diagnosis of PCOS in the primary care computer systems. However, PCOS is poorly coded in primary care records.

In order to recruit women with PCOS into a randomised control trial (4) we searched the electronic records of 39 general practices in our locality for coded diagnosis of Polycystic ovary syndrome. We found that the recorded prevalence of PCOS based on the estimated population of the reproductive age women (18-49 years old) was only $1.5 \%$ (range $0.3 \%$ to $3.1 \%$ ), Table 1 , which is far below what would be expected.

Table 1: Recorded prevalence of Polycystic Ovary Syndrome in 39 General Practices + based on the population under cover of these Practices

\begin{tabular}{|l|l|l|l|l|}
\hline $\begin{array}{l}\text { Population } \\
\text { under cover of }\end{array}$ & $\begin{array}{l}\text { Estimated number } \\
\text { of female } \ddagger\end{array}$ & $\begin{array}{l}\text { Estimated number of female } \\
\text { age } 18-49 \text { years old } \ddagger\end{array}$ & $\begin{array}{l}\text { Number of PCOS } \\
\text { patients identified }\end{array}$ & $\begin{array}{l}\text { Recorded } \\
\text { prevalence of PCOS }\end{array}$ \\
\hline 341720 & $173491(50.77 \%)$ & $74775(43.1 \%)$ & 1087 & $1.5 \%$ \\
\hline
\end{tabular}

† Based on the population under cover of these 39 General Practices

¥ Estimation is based on the data released by Office for National Statistics

(https://www.ons.gov.uk/) for 2012 (year that this recruitment happened).

\section{Key message}

It appears that there is significant under-recording of PCOS in primary care. Because of the long-term comorbidities associated with PCOS, the lack of appropriate monitoring (3) may have long term implications for both women with PCOS as well as health systems which may need to deal with future complications.

We suggest educational campaigns are needed targeting both women as well as health care professionals to increase awareness in primary care about PCOS, its implications and the care required for these patients. 
Hamidreza Mani (manihr@yahoo.com) ${ }^{1,2}$, Miles J Levy ${ }^{2}$, Kamlesh Khunti ${ }^{1}$

3- University of Leicester, Diabetes Research Centre, Leicester Diabetes Centre, Leicester General Hospital, Leicester, LE4 5PW, UK

4- Department of Diabetes and Endocrinology, Leicester Royal Infirmary, University Hospitals of Leicester NHS Trust, Leicester, LE1 5WW, UK

Key Words: Polycystic ovary syndrome, primary care, education, database, monitoring

Conflicts of interest: None related to the presented work.

\section{References}

(1) Fauser BC, et al. "Consensus on women's health aspects of polycystic ovary syndrome (PCOS): the Amsterdam ESHRE/ASRM-Sponsored 3rd PCOS Consensus Workshop Group". Fertil Steril 2012 Jan;97(1):28-38.e25.

(2) Mani $\mathrm{H}$, et al. "Diabetes and cardiovascular events in women with polycystic ovary syndrome: a 20-year retrospective cohort study". Clin Endocrinol (Oxf) 2013 Jun;78(6):926-934.

(3) Healed AH, et al. "Polycystic ovarian syndrome: Assessment of approaches to diagnosis and cardiometabolic monitoring in UK primary care". Int J Clin Pract. 2017 Dec 22. doi:

\subsection{1/ijcp.13046.}

(4) Mani et al. "Structured education programme for women with polycystic ovary syndrome: a randomised controlled trial" Endocr Connect 2018 vol. 7no. 1 26-35

This article is protected by copyright. All rights reserved 


\section{University Library}

\section{- M M I E E R VA A gateway to Melbourne's research publications}

Minerva Access is the Institutional Repository of The University of Melbourne

Author/s:

Mani, H;Levy, MJ;Khunti, K

Title:

Polycystic ovary syndrome: An underestimated problem in primary care

Date:

2018-04-01

Citation:

Mani, H., Levy, M. J. \& Khunti, K. (2018). Polycystic ovary syndrome: An underestimated problem in primary care. INTERNATIONAL JOURNAL OF CLINICAL PRACTICE, 72 (4), https://doi.org/10.1111/ijcp. 13081.

Persistent Link:

http://hdl.handle.net/11343/284096 